\title{
Study of Some Biomarkers Changes in Patients with Lupus Nephritis and Their Correlation with Disease Activity and Progression
}

\author{
Walaa A. Keshk*, Nema A. Soliman* and Noha S Esheba* \\ Departments of Medical Biochemistry* and Internal Medicine *, \\ Faculty of Medicine, Tanta University
}

\begin{abstract}
Background: Systemic lupus erythematosus (SLE) is a chronic multisystem autoimmune disease characterized by complex clinical manifestations and chronic inflammatory processes with failure of immunoregulatory mechanisms. Kidney is one of the most commonly affected organs. Considering the morbidity associated with SLE and particularly with lupus nephritis (LN), it is important to identify novel biomarkers of disease activity which could aid in the detection and assessment of flares and degree of activity. At present, activity of SLE is assessed based on clinical symptoms and biochemical parameters such as autoantibody (e.g antinuclear antibody (ANA)) and serum complement. However, these biomarkers are not specific for evaluating renal activity. Renal biopsy is the gold standard for assessment of kidney damage and disease activity, but its usage is restricted as it is an invasive procedure. Aim of the work: In the present study, plasma level of advanced oxidation protein products (AOPPs) and peripheral blood mononuclear cells nuclear factor- $\kappa B$ (PBMCs NF- $\kappa B$ ) level as well as serum levels of fetuin-A, 25-hydroxyvitamin $D$ (25OHD), calcium (Ca), inorganic phosphate were studied as novel biomarkers of LN activity and progression. Methods: The study included 30 SLE female patients, 15 without nephritis (group II) and 15 with nephritis (group III), in addition to 15 agematched healthy controls (group I). Overnight fasting blood was collected from all subjects for measurement of plasma AOPPs level, PBMCs $N F-\kappa B$ level and serum fetuin-A level, 25OHD level, $\mathrm{Ca}$ and inorganic phosphate levels as well as calculation of calcification risk index (CRI). Results: Plasma AOPPs, PBMCs $N F-\kappa B$, serum inorganic phosphate levels and CRI were significantly higher in SLE patients (group II) than age-matched healthy controls (group I) $(p<0.05)$ with the highest level in patients with LN (group III) meanwhile, serum fetuin-A and 25OHD levels were significantly lower in SLE patients than age-matched healthy controls $(p<0.05)$ with the lowest level in LN patient group. In addition plasma AOPPs, PBMCs NF- $\kappa B$ levels and CRI showed significantly positive correlation meanwhile, fetuin-A and $25 O H D$ levels showed significantly negative correlation with serum creatinine, 24 hours urinary albumin, erythrocyte sedimentation rate (ESR), $C$ reactive protein (CRP), ANA, anti double stranded DNA (Anti-dsDNA) antibodies levels and SLE disease activity index (SLEDAI). Conclusions: In SLE patients, high PBMCs NF- $\kappa B$ and plasma AOPPs levels as well as CRI while low levels of fetuin- $A$ and $25 O H D$ were related to disease activity and progression.
\end{abstract}


Key words: Systemic lupus erythematosus (SLE), lupus nephritis (LN), Advanced oxidation protein products (AOPPS), Peripheral blood mononuclear cells nuclear factor- $\kappa B$ (PBMCs NF- $\kappa B)$, Fetuin-A, 25-hydroxyvitamin D (25OHD), Calcification risk index (CRI)

\section{INTRODUCTION}

Systemic lupus erythematosus (SLE) is a multisystem autoimmune disorder with high morbidity and mortality. SLE characterized by chronic inflammation, abnormal immune system response with failure of immunoregulatory mechanisms ${ }^{(1)}$. SLE affects predominantly women of child-bearing age with multi-organ involvement and is characterized by variable clinical features, including glomerulonephritis, arthritis, and neuropsychiatric disease ${ }^{(2)}$. Kidney is one of the most commonly affected organs and lupus nephritis (LN) represents one of the most serious manifestations of SLE contributes to high mortality ${ }^{(3)}$.

Increased oxidative stress contributes to the pathogenesis of some diseases as chronic kidney disease and autoimmune diseases ${ }^{(4)}$. Advanced oxidation protein products (AOPPs) are dityrosine-containing cross-linking proteins, formed by the reaction between chlorinated oxidants and proteins and derived from oxidation-modified albumin, fibrinogen, and lipoproteins. AOPPs have a role in induction of macrophage activation and apoptosis ${ }^{(5)}$.

Patients with SLE demonstrate defective clearance of apoptotic cells which allows deposition of immune complexes that can stimulate B and $\mathrm{T}$ cells, causing tissue damage ${ }^{(6)}$. Nuclear factor kappa B (NF- $\mathrm{kB})$, is a heterodimeric complex composed of two subunits termed p50 and p65 and is a key transcription factor involved in the regulation of immune responses and apoptosis ${ }^{(7,8)}$.

Calciphylaxis and calcinosis are soft-tissue calcification associated with SLE morbidity and mortality ${ }^{(9)}$. Fetuin-A $\quad\left(\alpha_{2}\right.$-Heremans-Schmid glycoprotein AHSG) is glycoprotein predominantly synthesized in liver ${ }^{(\mathbf{1 0})}$. It is generally recognized as a calcification inhibitor rather than negative inflammatory marker, which facilitates the formation of soluble calciprotein particles and limits the formation of hydroxyapatite crystals $^{(\mathbf{1 0 )}}$.

25-hydroxivitamin D (25OHD) is one of sterols with a critical role in calcium, phosphorus metabolism, although vitamin $\mathrm{D}$ is consumed in food, dietary intake alone is often insufficient, supplying only $20 \%$ of the body's requirements ${ }^{(11)}$. The main source of vitamin $\mathrm{D}$ is the conversion of 7-dehydrocholesterol to previtamin $\mathrm{D}_{3}$ in the skin, by means of solar ultraviolet B (UVB) radiation. The fully active form, calcitriol $(1,25(\mathrm{OH}) 2 \mathrm{D})$, is synthesized in the kidneys $^{(12)}$. Vitamin D deficiency has a role in the development of neoplasm, cardiovascular disease, increased susceptibility to infections and autoimmune diseases. 25OHD is an immunomodulatory hormone through its inhibitory effect on $\mathrm{T}$ lymphocytes, B lymphocytes and 
dendrite cells as well as it can alter the cytokine production profile ${ }^{(13)}$.

The aim of the current study is to evaluate the relationship between AOPPs, NF- $\kappa$ B, fetuin-A and 25OHD level as well as calculated calcification risk index (CRI) and LN, and to evaluate their possible clinical significance in disease activity and progression.

\section{PATIENTS \& METHODS}

\section{Patients:}

The current work was carried out in Medical Biochemistry Department in accordance to the guidelines of the Ethical Committee of Medical Research, Faculty of Medicine, Tanta University, Egypt. An informed written consent was obtained from every patient and control subject. This current study was carried out on 45 premenopausal females. They were further subdivided into 3 groups. Group I $(n=15)$ healthy volunteers were recruited as controls, group II $(n=15)$ age matched SLE patients with no laboratory or clinical manifestations of nephritis and group III $(n=15)$ age matched LN patients who had survived one or more manifestations of nephritis. All patients were selected from the Inpatients and Outpatients Clinic of Internal Medicine Department, Tanta University Hospital, Egypt and they fulfilled four or more of the American College of Rheumatology revised criteria for diagnosis of SLE ${ }^{(14)}$. The SLE Disease Activity Index (SLEDAI) was assessed according to Bombardier et al. (1992) (15). SLEDAI assessment for renal involvement was used to assess kidney disease activity. The score consists of the four kidney-related parameters: hematuria, pyuria, proteinuria, and urinary casts. Scores for the renal SLEDAI can range from 0 (inactive renal disease) to a maximum of 16 . SLEDAI score of $\geq 4$ was taken as an indicator of active $\mathrm{LN}^{(15)}$.

All individuals of the study were subjected to full history taking, thorough clinical examination and those with a history of diabetes mellitus, coronary artery disease (CAD), malignancy, concurrent infection, other connective tissue disorders such as rheumatoid arthritis, liver or other kidney diseases and oral prednisolone greater than $10 \mathrm{mg}$ /day were excluded from the study.

Sample preparation:

Overnight fasting venous blood samples were aseptically collected. Part was collected in plane tubes, centrifuged and the recovered serum aliquots were stored at $-80^{\circ} \mathrm{C}$ for analysis of fetuin-A and 25OHD levels. For PBMCs NF- $\mathrm{BB}$ level and plasma AOPPs levels, another part of the blood sample was collected on plastic tubes containing $\mathrm{K}_{2}$ EDTA at a final concentration of $1.2 \mathrm{mg}$ EDTA $/ \mathrm{ml}$ and was used for plasma and PBMCs separation. Blood was added slowly along the sides of the tube containing Ficoll hypaque (Sigma Aldrich) and centrifuged at $400 \mathrm{x} \mathrm{g}$ for 20 minutes. PBMCs (white interphase layer), plasma (upper layer) and red blood cells (bottom layer) were carefully separated. Plasma sample was frozen at $-80^{\circ} \mathrm{C}$ until used for measurement of AOPPs level. The PBMCs were washed with phosphate buffer saline 
(PBS) $\mathrm{pH} 7.4$ three times. PBMCs were lysed with lysis buffer containing $0.2 \%$ Triton X-100, $0.25 \mathrm{M}$ sucrose, $10 \mathrm{mM}$ EDTA and $1 \mathrm{mM}$ $\mathrm{CaCl}_{2}$ (Sigma Aldrich) ${ }^{(\mathbf{1 6})}$. The lysate was centrifuged at $1600 \times \mathrm{g}$ for 10 minutes and supernatant was recovered. Samples were then kept at $-80^{\circ} \mathrm{C}$ until the time of assay for PBMCs NF- $\kappa$ B level.

Routine laboratory investigations were done and included urine analysis especially for 24 hours proteinuria using commercial kits supplied by Diamond Diagnostic, Egypt and RBCs casts, complete blood count, ESR-1 by Westergreen method, Fasting blood sugar (FBS) by oxidase method using commercial kit supplied by Biodiagnostic., Egypt, $\mathrm{C}$ reactive protein (CRP), serum albumin, serum creatinine all were estimated using commercial kits (Randox Laboratories Ltd., Diamond Diagnostic, Egypt). Antinuclear antibody (ANA) by commercial ELISA kit (Kallestad HEp-2 Kit., Biorad), anti double stranded DNA antibodies (antidsDNA) by commercial ELISA kit (Inova Diagnostics Inc., San Diego, USA) and renal biopsy for diagnosis of LN.

Biochemical Assessment included:-

1. Plasma AOPPs was assayed immediately spectrophotometric method according to Witko-Sarsat et al (1998) ${ }^{(18)}$.

2. Peripheral mononuclear cells NF-кB level (PBMCs NF- $\kappa$ B level) was determined by commercial ELISA kit (Uscn Life Science Inc.) E91824Hu.

3. Serum Fetuin-A level was measured by a commercial
ELISA kit (OmniKine ${ }^{\mathrm{TM}}$ ) Catalog Number OK-0329.

4. Serum 250HD level was measured by radioimmunoassay (RIA), (Nichols Institute Diagnostics, San Clemente, CA, USA). Values of $25 \mathrm{OHD} \leq 20$ $\mathrm{ng} / \mathrm{ml} \quad(50 \quad \mathrm{nmol} / \mathrm{L}) \quad$ were considered 25OHD deficient; values ranging from 21 to 29 $\mathrm{ng} / \mathrm{ml}$ (52 to $72 \mathrm{nmol} / \mathrm{L}$ ) were considered 25OHD insufficiency, and levels $\geq 30 \mathrm{ng} / \mathrm{ml}(75 \mathrm{nmol} / \mathrm{L})$ were considered sufficient for $25 \mathrm{OHD}^{(17)}$.

5. Serum Ca was measured by QuantiChrom $^{\text {TM }}$ Assay Kit (DICA-500).

6. Serum inorganic phosphate was measured by CHRONOLAB phosphomolybdate UV kit (1010458).

7. Calculation of calcification risk index $(\mathrm{CRI})=\mathrm{Ca} X \mathrm{P} /$ Fetuin-A. (Where: $\mathrm{Ca}, \mathrm{P}$ and fetuin- $\mathrm{A}$ are serum levels of $\mathrm{Ca}$, inorganic phosphate and fetuin-A, respectively) ${ }^{(\mathbf{1 9 )}}$.

Statistical analysis:

Statistical presentation and analysis of the present study was conducted, using the mean, standard deviation and Person correlation test (r) by SPSS version.16. . Analysis of variance [ANOVA] tests and Tukey's test was used to determine the significance between more than 2 groups: According to the computer program SPSS for Windows. $P$ value $<0.05$ was considered significant.

\section{RESULTS}

Table (1) shows statistical comparison between descriptive 
parameters among all studied groups. There were statistically insignificant differences in values of age and disease duration, however there were statistically significant differences in values of serum creatinine, 24 hours urinary albumin and ESR-1 among all studied groups (F value was 3.147, 21.121, and 10.37 respectively, $\mathrm{P}<0.05)$. Using multiple comparisons test (Tukey's test), the values were markedly higher in LN group (group
III) and SLE group (group II) compared to healthy control group (group I) with statistically higher level in $\mathrm{LN}$ group $(\mathrm{P}<0.05)$. There were statistically significant differences in values of CRP (mg/L), ANA (IU/ml), Anti-dsDNA (IU/ml) and SLEDAI score between LN patient group (group III) and SLE group (group II) $(\mathrm{p}<0.05)$ with statistically higher level in LN group.

Table 1: Statistical comparison between descriptive parameters among all studied groups

\begin{tabular}{|c|c|c|c|c|c|c|c|c|}
\hline \multirow[t]{2}{*}{ Parameters/Group } & \multirow{2}{*}{$\begin{array}{l}\text { Group I } \\
\mathbf{n}=15\end{array}$} & \multirow{2}{*}{$\begin{array}{l}\text { Group II } \\
\mathrm{n}=15\end{array}$} & \multirow{2}{*}{$\begin{array}{l}\text { Group III } \\
\mathrm{n}=15\end{array}$} & \multicolumn{2}{|c|}{ ANOVA test } & \multicolumn{3}{|c|}{ Tukey's test } \\
\hline & & & & $\mathbf{F}$ & $\mathbf{P}$ & P1 & P2 & P3 \\
\hline Age (vears) & $31.1 \pm 7.9$ & $35.1 \pm 10.3$ & $29.1 \pm 12.6$ & 0.735 & 0.231 & 0.352 & 0.639 & 0.441 \\
\hline $\begin{array}{l}\text { Duration of diagnosis } \\
\text { of SLE (month) }\end{array}$ & $\begin{array}{l}\text { Not } \\
\text { applicable } \\
\text { (NA) }\end{array}$ & $17 \pm 6$ & $12 \pm 3$ & - & - & - & - & 0.085 \\
\hline $\begin{array}{l}\text { Serum Creatinine } \\
(\mathrm{mg} / \mathrm{dl})\end{array}$ & $0.83+0.08$ & $0.92 \pm 0.09$ & $2.93 \pm 0.63$ & 3.147 & $0.049 *$ & 0.152 & $0.036^{*}$ & $0.031 *$ \\
\hline $\begin{array}{l}24 \text { hours urinary } \\
\text { albumin (mg/24 hours) }\end{array}$ & $64.25 \pm 3.36$ & $95.41 \pm 7.52$ & $6352.5 \pm 952.3$ & 21.12 & $0.001 *$ & $0.036^{*}$ & $0.001^{*}$ & $0.001 *$ \\
\hline $\begin{array}{l}\text { ESR-1 (mm/hour) } \\
(\text { Mean } \pm \text { SD) }\end{array}$ & $9.5 \pm 3.2$ & $61.47 \pm 8.63$ & $82.41 \pm 10.72$ & 10.36 & $0.002 *$ & $0.001^{*}$ & $0.001^{*}$ & $0.042 *$ \\
\hline CRP (mg/L) & -ve & $23.36+5.63$ & $49.63+12.25$ & 12.51 & $0.001 *$ & - & - & $0.030 *$ \\
\hline ANA (IU/ml) & $-\mathrm{ve}$ & $23.63+6.52$ & $43.18+5.96$ & - & - & - & - & $0.012^{*}$ \\
\hline Anti- dsDNA (IU/ml) & -ve & $76.52 \pm 12.41$ & $101.4 \pm 10.30$ & - & - & - & - & $0.028 *$ \\
\hline SLEDAI score & NA & $1.65+0.23$ & $5.96+2.10$ & - & - & - & - & $0.006^{*}$ \\
\hline
\end{tabular}

Significant at P-value $<0.05^{*} \quad P 1$ comparison between group I and II

P2 comparison between group I and III P3 comparison between group II and III

Table (2) and figure (1) (a,b,c,d and e) show comparative statistics of different biochemical studied parameters among all studied groups. There were statistically significant differences in values of plasma AOPPs $(\mu \mathrm{mol} / \mathrm{L}), \mathrm{PBMCs} \mathrm{NF}-$ $\kappa \mathrm{B}$ level $(\mathrm{ng} / \mathrm{ml})$ and CRI among all studied groups ( $\mathrm{F}$ values were 10.36, 9.634, and 11.61 respectively, $\mathrm{P}<$
0.05). Using multiple comparisons test (Tukey's test), the values were markedly higher in group III and group II when compared to group I with statistically higher values in group III. There were statistically significant lower levels of serum fetuin-A (pg/ml), and 25OHD (ng/ml) between group III and group II with statistically lower level in group III. 
Also, there were statistically insignificant differences in values of serum $\mathrm{Ca}(\mathrm{mg} / \mathrm{dl})$ and serum inorganic phosphate $(\mathrm{mg} / \mathrm{dl})$ between all studied groups, by using multiple comparisons test (Tukey's test), there were statistically significant differences between group I and III and between group II and III with statistically significant lower serum $\mathrm{Ca}$ and higher inorganic phosphate levels in group III than group I and group II. The significant differences in levels of previous parameters reflect their strong relation to $\mathrm{LN}$ disease activity and progression.

Table 2: Comparative statistics of different biochemical studied parameters among all studied groups

\begin{tabular}{|c|c|c|c|c|c|c|c|c|}
\hline \multirow[t]{2}{*}{ Parameters/Group } & \multirow{2}{*}{$\begin{array}{l}\text { Group I } \\
\mathrm{n}=15\end{array}$} & \multirow{2}{*}{$\begin{array}{l}\text { Group II } \\
n=15\end{array}$} & \multirow{2}{*}{$\begin{array}{l}\text { Group III } \\
n=15\end{array}$} & \multicolumn{2}{|c|}{ ANOVA test } & \multicolumn{3}{|c|}{ Tukey's test } \\
\hline & & & & f & $\mathbf{P}$ & P1 & $\mathbf{P 2}$ & P3 \\
\hline $\begin{array}{l}\text { AOPPs } \\
\text { L) }\end{array}$ & $22.52 \pm 5.36$ & $56.85 \pm 8.63$ & $74.52 \pm 12.98$ & 10.36 & $0.002 *$ & $0.001^{*}$ & $0.001 *$ & $0.001^{*}$ \\
\hline $\begin{array}{l}\text { PBMCs NF-кB level } \\
\text { (ng/ml) }\end{array}$ & $93 \pm 2.94$ & $45.63 \pm 9.35$ & $80.63 \pm 13.61$ & .634 & $0.001 *$ & $0.001 *$ & $0.001 *$ & $0.001 *$ \\
\hline $\begin{array}{l}\text { Serum fetuin-A level } \\
(\mathrm{pg} / \mathrm{ml})\end{array}$ & $95 \pm 0.10$ & 02 & $0.42 \pm$ & 6.219 & $0.006^{*}$ & $0.007 *$ & $0.003^{*}$ & $0.037 *$ \\
\hline $250 H$ & $.20 \pm 2.41$ & $22.03 \pm 4.09$ & $14.20+1.52$ & 7.002 & $0.006^{*}$ & $0.020^{*}$ & $0.019 *$ & $0.017^{*}$ \\
\hline Serun & $10.18 \pm 1.47$ & $8.3 \pm 1.06$ & $7.79 \pm 1.38$ & 0.963 & 0.135 & 0.528 & $0.038^{*}$ & $0.027 *$ \\
\hline $\begin{array}{l}\text { Serum inorganic } \\
\text { phosphate (mg/dl) }\end{array}$ & $3.52 \pm 0.41$ & $4.63 \pm 0.91$ & $5.62 \pm 0.51$ & 2.159 & 0.063 & 0.159 & $0.032 *$ & $0.015^{*}$ \\
\hline CRI & $34.49 \pm 5.44$ & $37 \pm 4.55$ & $73.7 \pm 15.36$ & 11.610 & $0.002 *$ & 0.236 & $0.001 *$ & $0.001 *$ \\
\hline
\end{tabular}

Significant at $P$-value $<0.05 * \quad P 1$ comparison between group I and II

P2 comparison between group I and III P3 comparison between group II and III

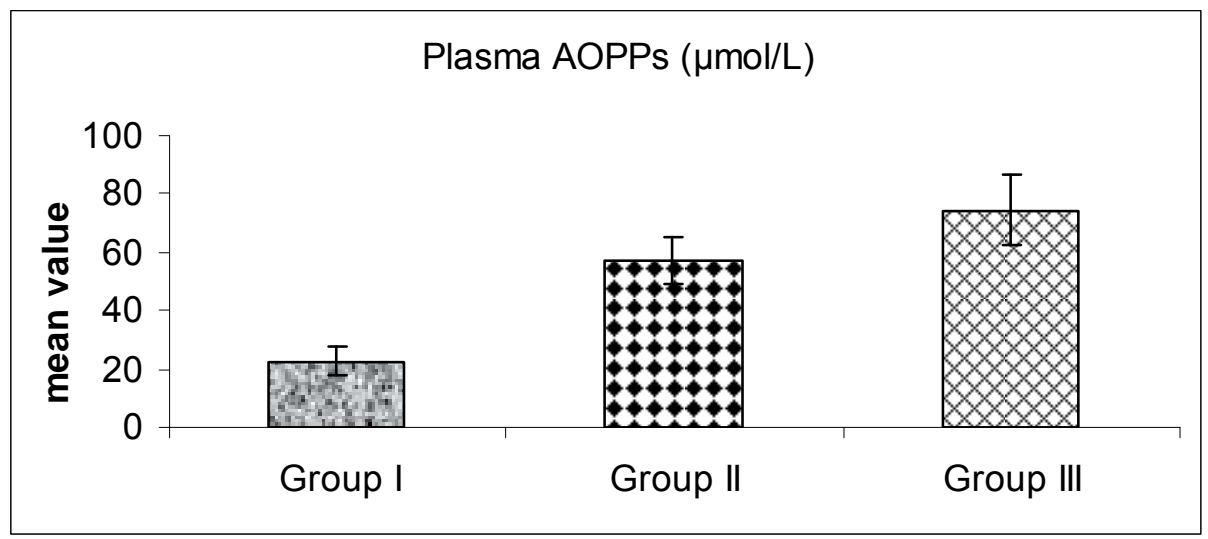

Fig. (1a): Comparison of Plasma AOPPs ( $\mu \mathrm{mol} / \mathrm{L})$ among all studied groups using ANOVA test 


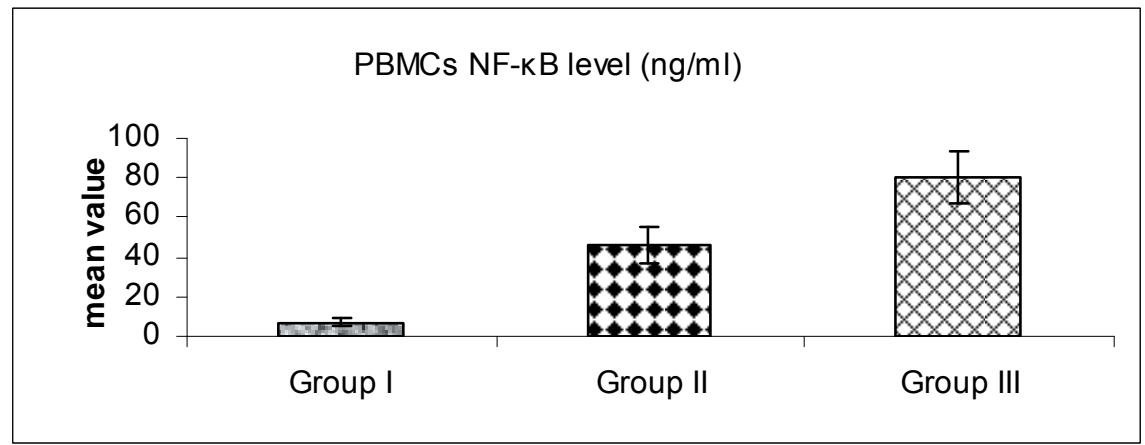

Fig. (1b): Comparison of PBMCs NF-кB level (ng/ml) among all studied groups using ANOVA test

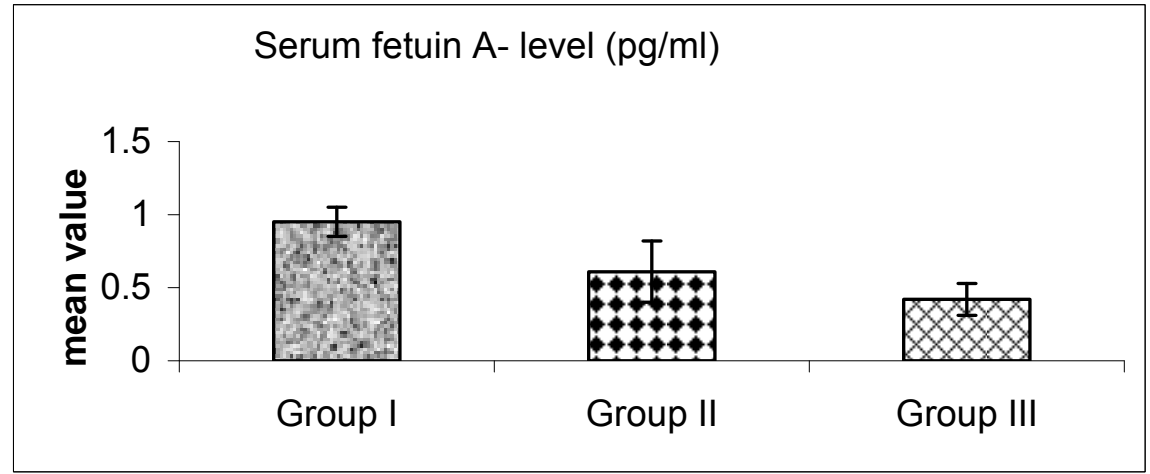

Fig. (1c): Comparison of serum fetuin-A level (pg/ml) among all studied groups using ANOVA test

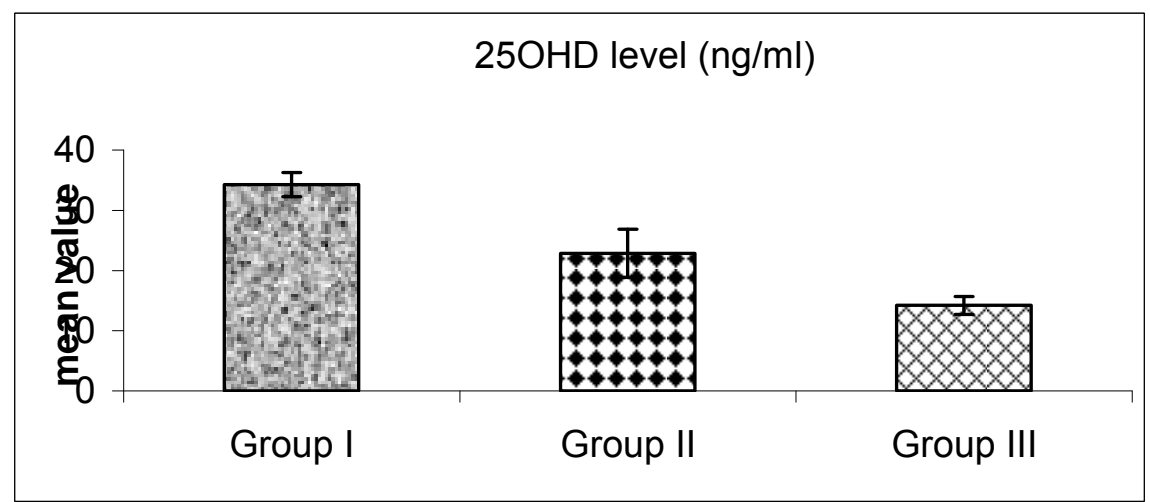

Fig. (1d): Comparison of serum 25OHD level (ng/ml) among all studied groups using ANOVA test 


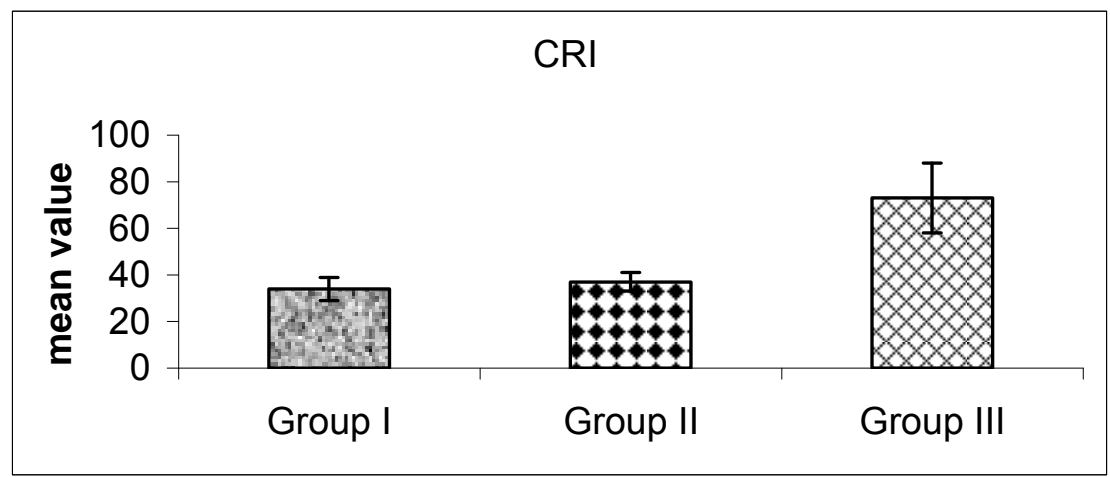

Fig. (1e): Comparison of CRI among all studied groups using ANOVA test

Table (3) shows person correlation between PBMCs NF- $\mathrm{BB}(\mathrm{ng} / \mathrm{ml})$ plasma AOPPs $\mu \mathrm{mol} / \mathrm{L}$ levels and CRI with serum levels of 25OHD $(\mathrm{ng} / \mathrm{ml})$ and fetuin-A $(\mathrm{pg} / \mathrm{ml})$ in patient groups (group II and III), negative correlations were found between PBMCs NF- $\kappa$ B $(\mathrm{ng} / \mathrm{ml})$, plasma AOPPs $(\mu \mathrm{mol} / \mathrm{L})$ levels and CRI with serum levels of both $25 \mathrm{OHD}(\mathrm{ng} / \mathrm{ml})$ and fetuin-A $(\mathrm{pg} / \mathrm{ml})$ in patient groups ( $\mathrm{r}$ value was -0.362 , $0.425,-0.419,-0.377,-0.296$ and -0.536 respectively, $\mathrm{P}<0.05)$.

Table 3: Correlation between PBMCs NF-kB (ng/ml), plasma AOPPs levels $(\mu \mathrm{mol} / \mathrm{L})$ and CRI with serum levels of $250 \mathrm{HD}(\mathrm{ng} / \mathrm{ml})$ and fetuin-A $(\mathrm{pg} / \mathrm{ml})$ in patient groups

\begin{tabular}{|c|c|c|c|c|c|c|}
\hline & \multicolumn{2}{|c|}{$\begin{array}{l}\text { Peripheral } \\
\text { lymphocyte NF-кB } \\
\text { level }(\mathrm{ng} / \mathrm{ml})\end{array}$} & \multicolumn{2}{|c|}{$\begin{array}{l}\text { Plasma } \\
\mu \mathrm{mol} / \mathrm{L}\end{array}$} & \multicolumn{2}{|l|}{ CRI } \\
\hline & $\mathbf{r}$ & $\mathbf{P}$ & $\mathbf{r}$ & $\mathbf{p}$ & $\mathbf{r}$ & p \\
\hline 25OHD level (ng/ml) & -0.362 & $0.009 *$ & -0.419 & $0.020 *$ & -0.296 & $0.007 *$ \\
\hline $\begin{array}{l}\text { Serum fetuin-A level } \\
(\mathrm{pg} / \mathrm{ml})\end{array}$ & -0.425 & $0.017^{*}$ & -0.377 & $0.006^{*}$ & -0.536 & $0.002 *$ \\
\hline
\end{tabular}

Significant at $P$-value $<0.05 *$

Table (4) shows person correlation between PBMCs NF-אB level (ng/ml) plasma AOPPs $\mu \mathrm{mol} / \mathrm{L}$ CRI, serum 25OHD level $(\mathrm{ng} / \mathrm{ml})$ and serum fetuin-A level $(\mathrm{pg} / \mathrm{ml})$ with some laboratory parameters in patient groups. Statistically significant positive correlation were found between PBMCs NF- $\mathrm{B}$ level (ng/ml), plasma AOPPs $(\mu \mathrm{mol} / \mathrm{L}), \mathrm{CRI}$ and serum creatinine $(\mathrm{mg} / \mathrm{dl}), 24$ hours urinary albumin (mg/24 hours), ESR-1 (mm/hour), CRP (mg/L), ANA (IU/ml), Anti-dsDNA antibodies (IU/ml), SLEDAI score. Meanwhile, serum levels of $25 \mathrm{OHD}(\mathrm{ng} / \mathrm{ml})$, fetuin-A ( $\mathrm{pg} / \mathrm{ml})$ showed statistically significant negative correlation with the above studied parameters. These results reflect the relationship of studied parameters to LN disease activity and progression. 
Table 4: Correlation of PBMCs NF-kB level $(\mathrm{ng} / \mathrm{ml})$ Plasma AOPPs $(\mu \mathrm{mol} / \mathrm{L})$, CRI, serum 25OHD level $(\mathrm{ng} / \mathrm{ml})$ and serum fetuin-A level $(\mathrm{pg} / \mathrm{ml})$ level with some laboratory parameters in patients groups

\begin{tabular}{|c|c|c|c|c|c|c|c|c|c|c|}
\hline & \multicolumn{2}{|c|}{$\begin{array}{l}\text { Peripheral } \\
\text { lymphocyte } \\
\text { NF-kB level } \\
(\mathrm{ng} / \mathrm{ml})\end{array}$} & \multicolumn{2}{|c|}{$\begin{array}{l}\text { Plasma } \\
\text { AOPPs } \\
\mu \mathrm{mol} / \mathrm{L}\end{array}$} & \multicolumn{2}{|l|}{ CRI } & \multicolumn{2}{|c|}{$\begin{array}{ll}\text { 25OHD } & \text { level } \\
(\mathrm{ng} / \mathrm{ml}) & \end{array}$} & \multicolumn{2}{|c|}{$\begin{array}{l}\text { Serum fetuin-A } \\
\text { level }(\mathrm{pg} / \mathrm{ml})\end{array}$} \\
\hline & $\mathbf{r}$ & p & $\mathbf{r}$ & p & $\mathbf{r}$ & $\mathbf{p}$ & $\mathbf{r}$ & $\mathbf{p}$ & r. & p. value \\
\hline $\begin{array}{l}\text { Serum creatinine } \\
(\mathrm{mg} / \mathrm{dl})\end{array}$ & 0.352 & $\because \cdot 1 \leqslant *$ & $\because \leqslant 1 V$ & $\because \cdots 7 *$ & $\cdot . \leqslant \wedge$ & $\because \cdots 7 *$ & -0.263 & $\because \cdot r V *$ & -0.550 & $\because \cdots *$ \\
\hline $\begin{array}{l}24 \text { hours urinary } \\
\text { albumin ( } \mathrm{mg} / 24 \\
\text { hours) }\end{array}$ & 0.285 & $\because \cdot Y \cdot *$ & $.0 Y \wedge$ & $\because \cdots 1 *$ & .199 & $\because \cdot r O *$ & -0.635 & $\because \cdots 1 *$ & -0.418 & $\because \cdots 9 *$ \\
\hline ESR-1 (mm/hour) & 0.417 & $\because \cdots 9 *$ & $\cdot r \cdot V$ & $\because$ YO* & מצזי & $\because .10 *$ & -0.410 & $\because \cdot Y \wedge *$ & -0.352 & $\because \cdot Y \wedge *$ \\
\hline CRP (mg/L) & 0.562 & $\because \cdots 1 *$ &.$\leqslant 10$ & $\because \cdots \vee *$ &.$\mu \mathrm{r}$ & $\because \cdot r \leqslant *$ & -0.320 & $\because . r q *$ & -0.295 & $\because \cdot \leqslant r^{*}$ \\
\hline ANA (IU/mI) & 0.314 & $\because \cdot \Gamma \leqslant *$ &. YVO & $\because \leqslant r^{*}$ & $\cdot Y V \varepsilon$ & $\because \cdot r \cdot *$ & -0.299 & $\because \cdot Y \wedge *$ & -0.305 & $\because \cdot$ ฯฯ* \\
\hline $\begin{array}{l}\text { Anti- dsDNA } \\
\text { (IU/ml) }\end{array}$ & 0.411 & $\because \cdot 1 \wedge *$ &. .219 & $\because \cdot Y 9 *$ & $\cdot{ }^{r}$. & $\because \cdot Y \wedge *$ & $-0 . r r q$ & $\because \cdot 1 \vee *$ & -0.418 & $\because \cdots 0 *$ \\
\hline SLEDAI score & $\cdot r \mu q$ & $\because \cdot 1 \cdot *$ &.$\mu 11$ & $\because . \Gamma 1 *$ &..$\$ 19$ & $\because \cdots \wedge *$ & -0.466 & $\because \cdots \leqslant *$ & $-0 . \varepsilon 1 \wedge$ & $\because \cdot 1 Y^{*}$ \\
\hline
\end{tabular}

Significant at $P$-value $<0.05$

\section{DISCUSSION}

Systemic lupus erythematosus is a chronic inflammatory autoimmune disease characterized by defective clearance of apoptotic cells with release of nuclear and cytoplasmic auto-antigens followed by chronic inflammation, auto-antibody production, immune complex formation and deposition in target organs such as the kidney leading to organ damage ${ }^{(20)}$. Nephritis is a major cause of morbidity and mortality in patients with lupus which may arise as a consequence of inflammation, cytokine, chemokine and adhesion molecule production with further influx of more inflammatory cells, tissue injury and fibrosis. End-stage renal disease in lupus is secondary to loss of glomerular and tubular function as a result of renal cell death and fibrosis ${ }^{(21)}$. Lymphocytes and their soluble mediators participate at all levels in disease pathogenesis and relapse ${ }^{(22)}$.

Excessive generation of reactive oxygen species (ROS), have the potential to initiate lipids, proteins and DNA modification and damage with generation of auto-antigens which can elicit autoimmune responses by stimulating $\mathrm{T}$ and $\mathrm{B}$ lymphocytes ${ }^{(23)}$. Advanced oxidation protein products represent a class of uremic toxins and/or pro-inflammatory mediators which contain larger amount of dityrosine, carbonyl groups and crosslinked bonds, they derived from oxidation modified albumin, fibrinogen, and lipoproteins ${ }^{(24)}$. AOPPs act as inflammatory mediators that result in excessive inflammatory 
response, through increased plasma levels of tumor necrosis factor- $\alpha$ (TNF- $\alpha$ ), enhanced neutrophils, monocytes and T-lymphocytes as well as macrophage invasion, smooth muscle cell (SMC) proliferation and excessive stimulation of dendritic cells with more oxidative stress ${ }^{(25)}$.

The current study revealed that patient groups had significantly higher level of AOPPs than control group with the highest level in LN patient, a finding in accordance with that of Lozovoy et al. ${ }^{(26)}$. That finding may reflect a state of inflammation and oxidative stress associated with SLE that is aggravated with nephritis. Significant higher plasma AOPPs level may be explained on the basis of SLE association with inflammatory cell infiltration as neutrophil. Neutrophils are rich in myeloperoxidase (MPO) enzyme which is the main factor for production of chlorinated oxidants that oxidize protein leading to the formation of AOPPs which have a role in induction of macrophage activation and apoptosis ${ }^{(27)}$.

Inflammatory cytokines like TNF- $\alpha$ and ROS are signals for the activation of NF- $\mathrm{KB}$ which is a family of transcription factors that contribute to the transcriptional regulation of several genes required for the immune response and is a heterodimeric complex typically composed of two subunits $\mathrm{p} 50$ and $\mathrm{p} 65$. NF- $\mathrm{\kappa B}$ remains inactive by binding to the inhibitory protein-kappa B (IкB) in the cytoplasm of many cell types as lymphocytes and monocytes ${ }^{(28,29)}$. IKB kinases (IKK) phosphorylate IкB exposing it to proteasomal degradation with subsequent release of free NF-kB; IKK activity is strongly induced by TNF- $\alpha$, interleukin1-beta (IL-1ß), B or $\mathrm{T}$ lymphocytes activation and oxidative stress ${ }^{(30)}$. Free NF- $\mathrm{KB}$ translocates to the nucleus, where it activates the transcription of genes involved in the inflammatory response, apoptosis and cell proliferation angiogenesis. Inflammatory cell infiltration and inflammatory cytokines cause glomerular and tubular injury, which may play a role in the pathogenesis of $\mathrm{LN}^{(31)}$.

Activation of NF- $\mathrm{KB}$ has an important role in maturation of dendritic cell, the professional antigen-presenting cells, capable of promoting either immunity or tolerance to specific antigens through induction of effector T-cell responses. Therefore, inhibition of NF-kB activation has been proposed as a strategy to maintain dendritic cell in an immature state to promote immune tolerance ${ }^{(32)}$.

The present study revealed that patient groups had significantly higher PBMCs NF- $\mathrm{kB}$ level than control group with the highest level in LN patient group, a finding in accordance with that of Zheng et al. and Kalergis et al. ${ }^{(33,34)}$. This result can be explained by state of chronic inflammation and oxidative stress associated with SLE which activates NF- $\kappa B$ mediated apoptosis of renal cells, so NF- $\mathrm{BB}$ may play an important role in mediating chronic renal injury, especially tubulointerstitial lesions that may be manifested clinically as progressive renal insufficiency and this run hand in hand with the results of the current study. 
Systemic lupus erythematosus is associated with leukocyte-mediated inflammatory state, tissue damage and bones demineralization. Tissue inflammation is often followed by deposition of type I collagen and may produce an alkaline environment, allowing calcium precipitation and alkaline phosphatase activation ${ }^{(35)}$. Calciphylaxis and calcinosis is the deposition of $\mathrm{Ca}$ and phosphate salts in soft-tissue and is associated with a number of metabolic and inflammatory disorders. So, controlling the SLE activity would help arrest or reverse soft tissue calcification $^{(36,37)}$.

Fetuin-A is a negative hepatic acute-phase glycoprotein belonging to the subgroup 3 of the cystatin superfamily, which also includes fetuin-B, histidine-rich glycoprotein, and kininogen ${ }^{(38)}$. Fetuin-A is involved in the regulation of calcified matrix metabolism through inhibition of ectopic $\mathrm{Ca}$ /phosphate ion precipitation and vascular calcification, it is responsible for approximately half of the precipitation inhibitory properties in the extracellular space through formation of protein-mineral complexes, called

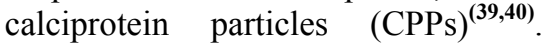
Fetuin-A is downregulated during an inflammatory process and has a role in attenuation of apoptosis, dystrophic calcification in atherosclerosis and downregulates vascular profibrotic activities ${ }^{(41)}$.

In the present study, serum fetuin-A was measured in SLE patients with and without nephritis in a trial to clarify its potential contribution to disease activity and progression. This current study revealed that patient groups had a significantly lower serum fetuin-A level than control group with the lowest level in LN patient group, a finding in agreement with those of Ketteler et al. $^{(42)}$ and Slough et al. $^{(43)}$. This result may be explained by: firstly, SLE associated inflammation which cause down regulation of fetuin-A gene expression, secondly, significant urinary loss of fetuin-A due to disease associated proteinuria and lastly, the polymorphism of fetuin-A gene may decrease its level ${ }^{(44)}$.

Vitamin $D$ is an essential hormone for bone/ mineral homeostasis, regulates the growth and differentiation of multiple cell types, and has an immunoregulatory and anti-inflammatory properties ${ }^{(\mathbf{4 5})}$. Cells involved in innate and adaptive immune responses, including macrophages, dendritic cells, T lymphocytes and B lymphocytes express the vitamin $\mathrm{D}$ receptor (VDR), and respond to $1,25(\mathrm{OH}) 2 \mathrm{D}$. 25OHD inhibits T-lymphocyte proliferation, dendritic cell differentiation, cytokine production and B lymphocytes antibody/ autoantibody production and secretion $^{(46,47)}$.

The current study revealed that patient groups had significantly lower serum level of 25OHD level than control group with the lowest level in LN patient group, and the reverse occurs for CRI, a finding in agreement with those of Kamen et al. ${ }^{(48)}$ Borba et al. ${ }^{(49)}$ and Bonakdar et al. ${ }^{(50)}$. This result may be explained by photosensitivity, renal involvement with defect in 1-Hydroxylation which is essential to make the active form of 
vitamin $\mathrm{D}$ and hydroxychloroquine used in SLE treatment which can lower the conversion of provitamin $\mathrm{D}_{3}$ to the active vitamin $\mathrm{D}_{3}$, also elevated inorganic phosphate level inhibits $25 \mathrm{OHD}$ conversion to $1,25(\mathrm{OH}) 2 \mathrm{D}^{(51)}$. The reduction in $1,25(\mathrm{OH}) 2 \mathrm{D}$ decreases intestinal absorption of $\mathrm{Ca}$ that causes hypocalcemia. Hyperphosphatemia leads to the development of renal bone disease, extraosseous calcifications of soft tissue and vasculature. Also, inorganic phosphate level more than $6.5 \mathrm{mg} / \mathrm{dl}$ and higher CRI is associated with increased risk of death ${ }^{(\mathbf{5 2})}$.

This current study revealed positive correlation between PBMCs NF- $\kappa \mathrm{B}$ level, AOPPs level and CRI with levels of creatinine, 24-hours urinary protein, ANA, anti-dsDNA antibodies, CRP, ESR-1 and SLEDAI, on the other hand an inverse correlation was detected with serum fetuin-A and 25OHD in SLE patient groups included in the present work. On the basis of these observations, it could be suggested that the decrease in the serum levels of fetuin-A and $25 \mathrm{OHD}$ and the increase in the levels of PBMCs NF- $\kappa$ B and plasma AOPPs's as well as CRI occur during the course of the disease activity and progression.

\section{CONCLUSION}

Excessive production of ROS disturbs redox status and can modulate the expression of inflammatory chemokines through $\mathrm{NF}-\kappa \mathrm{B}$ leading to inflammatory processes and tissue damage, which was more profound with LN and could reflect disease activity, considering antioxidants as a novel therapeutic strategies are important in SLE patients and patients with LN. The correlations between inflammation mediated changes in the fetuin-A level (an endogenous inhibitor of calcification) and 25OHD deficiency with abnormalities in calcium-phosphate metabolism represented in CRI are associated with disease activity in SLE patients in the form of renal impairment. Routine screening for $25 \mathrm{OHD}$ deficiency and its prompt treatment in patients with SLE is recommended. Also, correlation studies between the studied parameters and kidney function can reflect their role as a novel disease activity monitoring biomarkers.

Acknowledgements: The authors would like to thank all of the patients included in the work.

\section{REFERANCES}

1. Rahman A and Isenberg DA (2008): Systemic lupus erythematosus. N Engl J Med., 358(9):929-939.

2. Shao WH and Cohen PL (2011): Disturbances of apoptotic cell clearance in systemic lupus erythematosus. Arthritis Research \& Therapy 13(1):202-208.

3. Nowling TK and Gilkeson GS (2011): Mechanisms of tissue injury in lupus nephritis. Arthritis Res Ther., 13(6):250-258.

4. Valko M, Leibfritz $D$, Moncol J, Cronin MT, Mazur M, Telser J. (2007): Free radicals and antioxidants in normal physiological functions and 
human disease. Int. J. Biochem. Cel.1 Biol., 39(1): 44-84.

5. Liu SX, Hou FF, Guo ZJ, Nagai R, Zhang WR, Liu ZQ, Zhou ZM, Zhou M, Xie D, Wang GB and Zhang $X$ (2006): Advanced oxidation protein products accelerate atherosclerosis through promoting oxidative stress and inflammation. Arterioscl. Throm. Vas. Biol., 26(5):1156-1162.

6. Herrmann M, Voll RE, Zoller OM, Hagenhofer M, Ponner BB and Kalden JR (1998): Impaired phagocytosis of apoptotic cell material by monocyte-derived macrophages from patients with systemic lupus erythematosus. Arthritis Rheum., 41(7):12411250.

7. Hayden MS and Ghosh S (2004): Signaling to $N F-\kappa B$. Genes Dev., 18(18):2195-2224.

8. Siebenlist $U$, Brown $K$ and Claudio E (2005): Control of lymphocyte development by nuclear factor- $\kappa B$. Nat. Rev. Immunol., 5(6):435-445.

9. Rogers NM, Teubner DJ and Coates PT (2007): Calcific uremic arteriolopathy: advances in pathogenesis and treatment. Semin. Dial., 20(2): 150- 157.

10. Schafer C, Heiss A, Schwarz A, Westenfeld R, Ketteler $\mathbf{M}$, Floege J, Muller-Esterl W, Schinke $T$ and Jahnen-Dechent W (2003): The serum protein alpha 2- Heremans-Schmid glycoprotein/fetuin-A is a systemically acting inhibitor of ectopic calcification. J. Clin. Invest., 112(3): 357-366.
11. Amital H, Szekanecz Z, Szucs G, Dankó K, Nagy E, Csépány T, Kiss E, Rovensky J, Tuchynova A, Kozakova D, Doria A, Corocher N, AgmonLevin N, Barak V, Orbach H, Zandman-Goddard $G$ and Shoenfeld Y (2010): Serum concentrations of $25-\mathrm{OH}$ vitamin $\mathrm{D}$ in patients with systemic lupus erythematosus (SLE) are inversely related to disease activity: is it time to routinely supplement patients with SLE with vitamin D. Ann. Rheum. Dis., 69(6): 1155-1157.

12. Holick MF (2004): Vitamin D: importance in the prevention of cancers, type 1 diabetes, heart disease and osteoporosis. Am. J. Clin. Nutr., 79(3):362-671.

13. Kamen $D$ and Aranow $C$ (2008): Vitamin D in systemic lupus erythematosus. Curr. Opin. Rheumatol., 20(5): 532-537.

14. Hochberg MC (1997): Updating the American College of Rheumatology revised criteria for the classification of systemic lupus erythematosus. Arthritis Rheum., 40(9):1725.

15. Bomberdier C, Gladman DD, Urowitz MB, Caron D and Chang CH (1992):: Derivation of the SLEDAI. A disease activity index for lupus patients. The Committee on Prognosis Studies in SLE. Arthritis Rheum., 35(6):630-640.

16. Lenton KJ, Therriault $H$, Fülöp T, Payette $H$ and Wagner JR. (1999): Glutathione and ascorbate are negatively correlated with oxidative DNA damage in human 
lymphocytes. Carcinogenesis 20 (4): 607-613.

17. Holick MF (2007): Vitamin D deficiency. N. Engl. J. Med., 357(3):266-281.

18. Witko-Sarsat V, Friedlander $M$, Capeillère-Blandin $C$, Nguyen- Khoa T, Nguyen AT, Zingraff $J$, Jungers $P$ and Descamps-Latscha B (1996): Advanced oxidation protein products as a novel marker of oxidative stress in uremia. Kidney Int., 49(5); 1304-1313.

19. Osama F. Mosa, Ibrahim H. Mohamad and Magdi $M$. Salama (2012): Relationship between Fetuin-A and Systemic Lupus Erythematosus as a Predictor Marker for Atherosclerosis. American Medical Journal, 3 (2): 249-254.

20. Perl A (2010): Pathogenic mechanisms in systemic lupus erythematosus. Autoimmunity 43(1):1-6.

21. Li Y, Tucci M, Narain S, Barnes EV, Sobel ES, Segal MS and Richards HB (2006): Urinary biomarkers in lupus nephritis. Autoimmun. Rev., 5(6) 383-388.

22. Foster MH (2007): $\mathrm{T}$ cells and $\mathrm{B}$ cells in Lupus Nephritis. Semin. Nephrol., 27(1): 47-58.

23. Wang G , Pierangeli SS, Papalardo E, Ansari GA and Khan MF (2010): Markers of oxidative and nitrosative stress in systemic lupus erythematosus: Correlation with disease activity. Arthritis Rheum., 62(7): 20642072.

24. Piwowar A (2010): Advanced oxidation protein products. Part I.
Mechanism of the formation, characteristics and property. Pol. Merkur. Lekarski., 28(164); 166169.

25. Alderman CJ, Shah $S$, Foreman JC, Chain BM and Katz DR (2002): The role of advanced oxidation protein products in regulation of dendritic cell function. Free Radical Biol. Med., 32(5): 377-385.

26. Lozovoy MA, Simão AN, Panis C, Rotter MA, Reiche EM, Morimoto HK, Lavado E, Cecchini R and Dichi I (2011): Oxidative stress is associated with liver damage, inflammatory status, and corticosteroid therapy in patients with systemic lupus erythematosus. 20(12):1250-1259

27. Yang XB, Hou FF, Wu Q, Zhou H, Liu ZR, Yang $Y$ and Zhang $X$ (2005): Increased levels of advanced oxidation protein products are associated with atherosclerosis in chronic kidney disease. Zhonghua Nei $\mathrm{Ke} \mathrm{Za}$ Zhi., 44(5); 342-346.

28. Iruretagoyena MI, Sepulveda SE, Lezana JP, Hermoso M, Bronfman M, Gutierrez MA, Jacobelli SH and Kalergis AM (2006): Inhibition of nuclear factor-kappa B enhances the capacity of immature dendritic cells to induce antigen-specific tolerance in experimental autoimmune encephalomyelitis. J. Pharmacol. Exp. Ther., 318(1):59-67.

29. Cominacini L, Anselmi $M$, Garbin U, Fratta Pasini A, Stranieri C, Fusaro M, Nava C, Agostoni P, Keta D, Zardini P, 
Sawamura T and Lo Cascio V (2005): Enhanced plasma levels of oxidized low-density lipoprotein increase circulating nuclear factor-kappa $\mathrm{B}$ activation in patients with unstable angina. J. Am. Coll. Cardiol., 46(5):799806.

30. Kurylowicz A and Nauman J (2008): The role of nuclear factor- $\kappa \mathrm{B}$ in the development of autoimmune diseases: a link between genes and environment. Acta Biochem. Pol., 55 (4): 629647.

31. Zheng L, Sinniah R, and Hsu SI(2008): Pathogenic role of NF$\kappa \mathrm{B}$ activation in tubulointerstitial inflammatory lesions in human lupus nephritis. J. Histochem. Cytochem., 56(5): 517-529.

32. Tan PH, Sagoo $P$, Chan C, Yates JB, Campbell J, Beutelspacher SC, Foxwell BM, Lombardi $G$ and George AJ (2005) : Inhibition of NF-kappa B and oxidative pathways in human dendritic cells by antioxidative vitamins generates regulatory $\mathrm{T}$ cells. J. Immunol., 174(12):76337644.

33. Zheng $L$, Sinniah $R$ and Hsu SI (2006): Renal cell apoptosis and proliferation may be linked to nuclear factor-kappa B activation and expression of inducible nitric oxide synthase in patients with lupus nephritis. Hum. Pathol., 37(6):637-647.

34. Kalergis AM, Iruretagoyena MI , Barrientos MJ , González PA, Herrada AA, Leiva ED, Gutiérrez MA, Riedel CA, Bueno SM and Jacobelli SH (2009) : Modulation of nuclear factor- $\kappa \mathrm{B}$ activity can influence the susceptibility to systemic lupus erythematosus. Immunology 128(1 suppl.): e306314.

35. Boulman N, Slobodin G, Rozenbaum $M$ and Rosner I (2005): Calcinosis in rheumatic diseases. Semin. Arthritis Rheum., 34(6): 805-812.

36. Mandelbrot DA, Santos PW., Burt RK, Oyama Y, Block GA, Ahya SN, Rosa RM and Traynor AE (2008): Resolution of SLE-related soft-tissue calcification following hematopoietic stem cell transplantation. Nephrol. Dial. Transplant., 23(8): 2679-2684.

37. Asanuma Y, Oeser A, Shintani AK, Turner E, Olsen N, Fazio S, Linton MF, Raggi P, Stein CM. (2003): Premature coronary artery atherosclerosis in systemic lupus erythematosus. N. Engl. J. Med., 349(25): 2407-2415.

38. Lee $C$, Bongcam-Rudloff $E$, Sollner C, Jahnen-Dechent W and Claesson-Welsh $L$ (2009): Type 3 cystatins; fetuins, kininogen and histidine-rich glycoprotein. Front. Biosci., 14:2911-2922.

39. Herrmann M, Schäfer C, Heiss A , Gräber S, Kinkeldey A, Büscher A , Schmitt MM, Bornemann J , Nimmerjahn F, Herrmann M, Helming L, Gordon $S$ and Jahnen-Dechent W (2012) : Clearance of fetuinA-containing calciprotein particles is mediated by scavenger receptor-A. Circ. Res., 111(5): 575-584. 
40. Heiss A, DuChesne A, Denecke B, Grötzinger J, Yamamoto K, Renné $T$ and Jahnen-Dechent W (2003): Structural basis of calcification inhibition by alpha 2-HS glycoprotein/fetuin-A: Formation of colloidal calciprotein particles. J. Biol. Chem., 278(15): 13333-13341.

41. Cozzolino M, Galassi A, Biondi ML, Turri O, Papagni S, Mongelli N, Civita L, Gallieni $M$ and Brancaccio D (2006) : Serum fetuin-A levels link inflammation and cardiovascular calcification in hemodialysis patients. Am. J. Nephrol., 26(5): 423-429.

42. Slough S, Servilla KS, Harford AM, Konstantinov KN, Harris $A$ and Tzamaloukas AH (2006): Association Between Calciphylaxis and Inflammation in Two Patients on Chronic Dialysis. Adv. Perit. Dial., 22: 171-174.

43. Ketteler M, Bongartz $P$, Westenfeld R, Wildberger JE, Mahnken AH, Bohm R, Metzger T, Wanner C, JahnenDechent $W$ and Floege $J$ (2003): Association of low fetuin-A (AHSG) concentrations in serum with cardiovascular mortality in patients on dialysis: a crosssectional study. Lancet 361(9360):827-833.

44. Ziółkowska H, Wojnar J, Pańczyk-Tomaszewska $M$ and Roszkowska-Blaim M (2006): Fetuin-A in children with renal diseases. Przegl. Lek., 63(Suppl., 3):54-56
45. Cutolo $M$ and Otsa $K$ (2008): Vitamin D, immunity and lupus. Lupus 17(1): 6-10.

46. Szodoray $P$, Tarr T, Bazso A, Poor G, Szegedi $G$ and Kiss $E$ (2011): The immunopathological role of vitamin $\mathrm{D}$ in patients with SLE: data from a single centre registry in Hungary. Scand. J. Rheumatol., 40(2):122-126.

47. Arnson $Y$, Amital $H$ and Shoenfeld Y (2007): Vitamin D and autoimmunity: new etiological and therapeutical considerations. Ann. Rheum. Dis., 66(9): 1137-1142.

48. Kamen DL, Cooper GS, Bouali H, Shaftman SR, Hollis BW and Gilkeson GS (2006): Vitamin D deficiency in systemic lupus erythematosus. Autoimmun. Rev., 5(2): 114-117.

49. Borba VZ, Vieira JG, Kasamatsu T, Radominski SC, Sato EI and Lazaretti-Castro $M$ (2009): Vitamin D deficiency in patients with active systemic lupus erythematosus. Osteoporos. Int., 20(3):427-433.

50. 50- Bonakdar ZS, Jahanshahifar L, Jahanshahifar F and Gholamrezaei A (2011): Vitamin D deficiency and its association with disease activity in new cases of systemic lupus erythematosus. Lupus 20(12), 1155-1160.

51. Kestenbaum B, Sampson JN, Rudser KD, Patterson DJ, Seliger SL, Young B, Sherrard DJ and Andress DL (2005): Serum phosphate levels and mortality risk among people with 
chronic kidney disease. J. Am.

Society Nephrol., 16(2):520-528.

52. Block GA, Hulbert-Shearon TE, Levin NW and Port FK (1998): Association of serum phosphorus and calcium $\mathrm{x}$ phosphate product with mortality risk in chronic hemodialysis patients: a national study. Am. J. Kid. Dis., 31(4):607-617. 
دراسة التغير في بعض الالائل الكيميائية في مرضى الأئبة الحمراء المصاحب

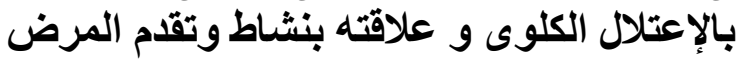

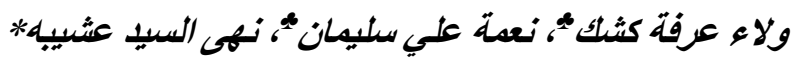

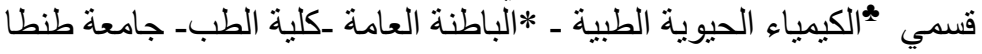

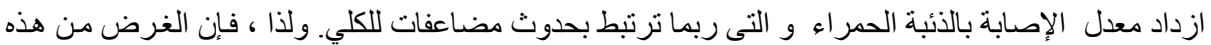

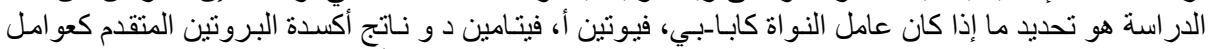

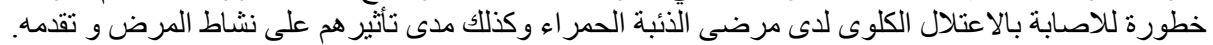

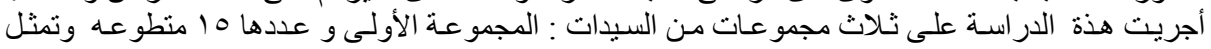

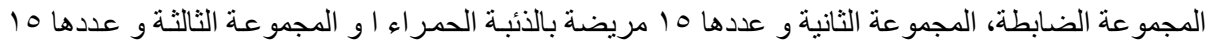

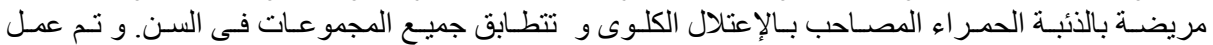

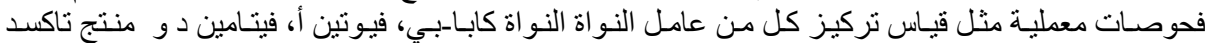

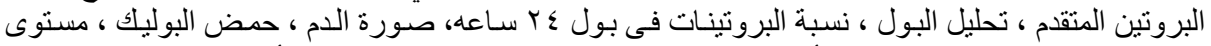

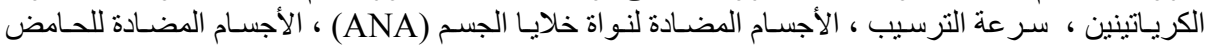

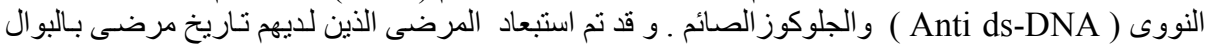

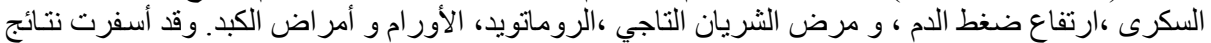

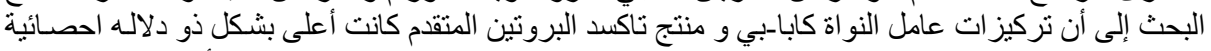

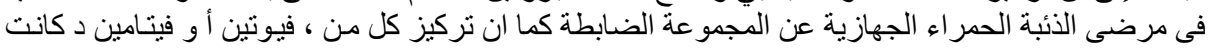

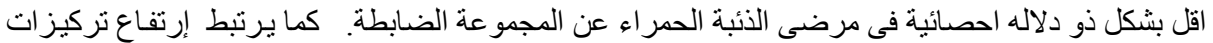

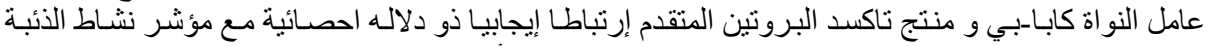

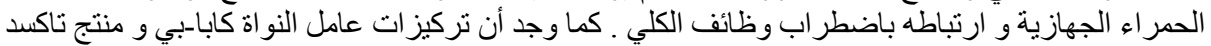

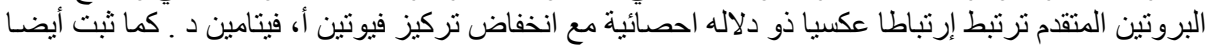

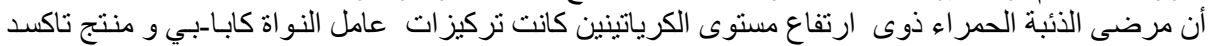

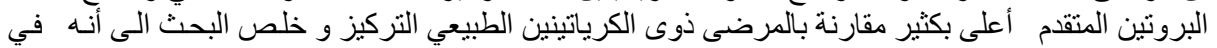

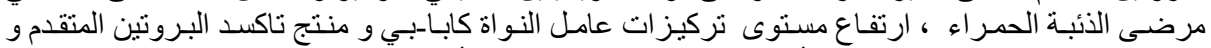

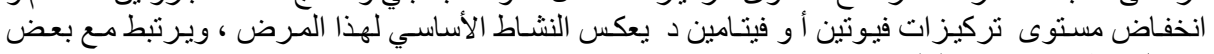
عو امل خطورة اصنابة الكلي. 